\title{
Critical Thinking in English Academic Essay: Indonesian Teacher's Voices
}

\author{
Rizka Safriyani \\ Faculty of Education and Teachers Training \\ UIN Sunan Ampel \\ Surabaya, Indonesia \\ rizkasafriyani@uinsby.ac.id \\ Laras Ayuningtyas M. \\ Faculty of Education and Teachers Training \\ UIN Sunan Ampel \\ Surabaya, Indonesia \\ larasuinsa@gmail.com
}

\begin{abstract}
This study was intended to explore teachers perspective in academic writing, critically. The design of this research was qualitative descriptive. This research involved three teachers as the participants who taught writing course at English Language Education Department of UIN SunanAmpel Surabaya. The data was collected through an interview. The result of the research demonstrates that all teachers have already known the definition of critical thinking in academic writing and they have already implemented critical thinking in the process of teaching writing. They also categorized the characteristics of critical thinking in academic writing such as giving reasonable judgement, having unique ideas, delivering the idea, and doing a concise summary.
\end{abstract}

Keywords: critical thinking, academic writing, teachers' perception

\section{INTRODUCTION}

In this era, critical thinking is an essential requirement and desired outcomes for students in higher education. The Indonesian government requires every teacher should stimulate students' critical thinking which is important for their future as it can develop the quality of students' intellectual thought (Kemendikbud, 2013). Critical thinking is an attitude of being disposed to consider problems and subjects that come within the range of one's experience, knowledge of the logical enquiry method, reasoning and some skills in thoughtfully applying those methods (Glaser, 2011). Likewise, critical thinking calls for a persistent effort to examine any belief or supposed form of knowledge in the light of the evidence that supports it and the further conclusions to which it tends. Critical thinking presents a rational motive which focused on what to believe (Ennis, 2011).

Critical thinking is necessary for teachers and students in assessing and completing assignments. Besides, teachers' understanding of applying critical thinking skills is varied from one another. It has become one of the weaknesses of why students are hard to write critically as every teacher has different criteria. However, critical thinking in academic writing bewilders for some students to write critically for some reasons. Vyncke (2012) revealed that the problems faced by postgraduate students in writing critically due to

\author{
Nur Hamidatul M. \\ Faculty of Education and Teachers Training \\ UIN Sunan Ampel \\ Surabaya, Indonesia \\ iidmalik12@gmail.com \\ Wichda Erika F. \\ Faculty of Education and Teachers Training \\ UIN Sunan Ampel \\ Surabaya, Indonesia \\ wichdaerika@gmail.com
}

fickleness in demonstrating the ideas, lack of prior knowledge, and problematic issues related to the topic. The problems faced by Indonesian students in writing critically are to obtain the ideas, to establish the existing ideas, and to associate the ideas. It is also supported by Cavdar and Deo (2012) implied that the number of problems faced by political-science classroom was weakly constructed and substantiated arguments, lack of precision and clear comprehension, difficulty in demonstrating the arguments and supplying the evidence, lack of organized, convincing, rich and elaborate responses to the questions at hand, and unwillingness to integrate the feedback that tutors provide on drafts. Besides, Indonesian lectures have implemented some strategies to stimulate students' critical thinking, such as writing an outline, giving a list of transition words, commanding the students to do paraphrasing, and summarizing paragraphs.

Meanwhile, having critical thinking is crucial in logically expressing students' idea and mastering their language skills (Lau, 2012). Moreover, students, especially at postgraduate level, should have critical thinking to write a thesis as their graduation requirement. The students in higher education need to be critical in writing a thesis, it helps them to summarize, to paraphrase and to make a clear, coherence, and cohesion interpretations (Davies, 2015). Besides, critical thinking is not only used in writing a thesis but also in writing another kind of academic writing, such as writing an essay, paper, article, proposal, report, etc. Those assignments require the students to have very good ideas, to sequence their ideas comprehensively, novelty and grammatical accuracy. There are five levels of intellectual activity that are essential to critical thinking which can develop students' ability in doing assignments, such as inference, recognition of assumption, deduction, interpretation, and evaluating of arguments (Watson and Glaser, 1952).

The embodiment of critical thinking in academic writing is highly valued in higher education, because it enhances students' ability in expressing their ideas explicitly, accurately and appropriately. In academic writing, the students should be critical to think the strengths and weaknesses of the ideas that they have gained (Moore, 2011). Writing critically can be acquired by having several criteria, 
such as showing a clear idea, using relevant sources, justifying the judgement from each source, giving good suggestions and hypotheses, presenting logical arguments and having self-corrective (Moore, 2011; Vallis, 2010). Furthermore, there are four levels on intellectual activity that are essential in critical writing, the first is an inference which means the ability to obtain logical conclusions. The second is recognizing assumptions which mean the ability to acknowledge assumptions and presuppositions implicitly. The third is deductions which mean the ability to evaluate propositions of the evidence. The fourth is the evaluation of arguments which means the ability to differ relevant, strong and weak arguments (Watson and Glaser, 1952). Another important rationale is that critical thinking is necessary since teachers take a role in inculcating critical thinking in their works since they require this to be involved in the students' works.

Therefore, it is needed further exploration to understand and to explain the existing phenomena of critical thinking implementation in writing. The researchers believe that teacher in writing class must have the standard of critical reflection throughout the design course. The main inquiries which drive this research are the interpretation of critical thinking in academic writing, the influences of critical thinking in academic writing, how to improve critical thinking in academic writing, and the indication of good critical thinking for good academic writing. By highlighting the patterns of teachers' perspectives concerning the study questions, the study is expected to develop a greater understanding for students in writing critically and raise awareness for teachers to better facilitate the students' expression in applying critical thinking ability in academic writing.

Here are the research questions along with the objectives of this study:

\section{RESEARCH QUESTION}

A. What are the interpretations of Critical thinking in Academic Writing?

B. What are the influences of Critical thinking in Academic Writing?

C. How to improve Critical thinking in Academic Writing?

D. Does good writing indicate good Critical thinking?

\section{OBJECTIVE OF THE STUDY}

A. To explore the interpretation of Critical thinking in Academic Writing

B. To explore the influences of Critical thinking in Academic Writing

C. To examine how to improve Critical thinking in Academic Writing.

D. To investigate the indication of good Critical thinking for good Academic Writing.

\section{LITERATURE REVIEW}

This second chapter elaborates important and related theories about critical thinking in academic writing and other points among them. Those theories are expressed and provided with some related points that regularly give a clear explanation used as the basis of argumentation for the research findings and discussions.

\section{A. Definition of Critical Thinking}

The conceptual framework in this literature review brings several types of research related to the definition, components, and influences. The guiding research in this study related to the definition of critical thinking is based on Glaser (2011). Glaser defined critical thinking as an attitude of being disposed to consider thoughtfully the problems and subjects that come within the range of one's experience, knowledge of the methods of logical enquiry and reasoning, and some skills in applying those methods. Critical thinking calls for a persistent effort to examine any belief or supposed form of knowledge in the light of the evidence that supports it and the further conclusions to which it tends. Another guiding research related to the components of critical thinking in writing skills is mentioned by Bensley and Murtagh (2012), which is acquiring knowledge by providing well-reasoned skills and self-regulation refers to human strategies in thinking. Saiz and Rivas (2011) also mentioned the components of critical thinking skills which are reasoning, problem-solving, and decision making. It will be easier for students in enhancing critical thinking skill. While another definition of critical thinking is asserted by Dewey (2011) is the supportive ideas which are constant and active. From those theories above, this research used Glaser's theory as the main indicator of this research which covers the definition of critical thinking, because his theory is substantial for the use of critical thinking in higher education.

\section{B. The Components of Critical Thinking in Academic Writing}

Critical thinking has an essential role in students' academic writing. Critical writing can be accessed by looking for some components. The study from Vyncke (2012) has investigated that the components of critical thinking in writing is based on someone who evaluates the writing as an expert of a certain field. Another component of writing came up from Noys (2013), those are the use of footnotes, role models, and style. One thing that distinguishes academic writing from most other forms of writing is the use of referencing or the use of the footnote, as it is a mark of critical thinking and it's worth thinking about why this is. Besides, one way to improve academic writing is to think about how others write. In this case, students are asked to decide which writing style is by their writing. Furthermore, the last components mentioned by Noys (2013) is having own style in writing to attract the readers. 


\section{Difficulties in Writing Critically}

Critical thinking can be obtained by the students as long as they notice the feedback from the teachers and evaluate their mistakes. Unfortunately, the students nowadays are rarely paying attention to teachers' feedback and they do not evaluate their mistake in doing assignments so that they would do the same mistake and cannot develop their critical thinking well. Students who do not pay attention to teachers' feedback potentially do the same mistake in their writing (Cavdar and Doe, 2012).Other difficulties faced by students are to combine one idea to another idea, to look for an idea, and to demonstrate the idea. Moreover, it also supported by Vyncke (2012) who mentions that the difficulties faced by students are lack of examining the problems of subject knowledge, manifesting their ideas in writing, and developing and presenting the argument.

\section{Improving Critical Thinking skill in Academic Writing}

This research revealed that the students in SunanAmpel Islamic State University do not apply critical thinking in academic writing. The approximately level of students' critical thinking in writing class is $30-50 \%$ as it is their first experience for having a writing class so that they do not get used to it before. The underlying factors of that phenomena are their experiences in their previous education and their first year in the university which do not require them to apply their critical thinking. Besides, The lecturers do not teach critical thinking as an independent skill, however, they apply critical thinking skill in the process of writing such as how to support the idea, how to make a draft, and how to develop their argument and show the evidence to improve the students critical thinking skills.

\section{E. Critical Thinking in Indonesian Academic Writing}

Indonesian postgraduate students are required to think critically in writing as it becomes the highest level in their study. To illustrate, one of a state university in Surabaya requires the students to take 10 credits of academic writing divided by 4 academic writing, 3 quantitative research, and 3 qualitative research. Besides, the critical thinking skill will be entailed in writing the thesis as the requirements to graduate. The aims of applying critical thinking in writing academically are to defend the arguments against bias, lack of supporting evidence, and incompleteness. Furthermore, critical thinking enables the students as a reader to assess what they have read by providing the evidence. Thinking critically will also help postgraduate students to create strong arguments in their writing. It means that the students will be able to present and defend any claims they make based on the evidence. Thus, involving critical thinking skills begins with an understanding of the relationship between writing and critical thinking.

\section{METHOD}

This study used qualitative research since it is best to address the research problem which needs to explore. This study was aimed to describe the phenomena of study that needs to learn more from participants through exploration. The form of the phenomenon includes an activity, the characteristic, the changes, the relations, the similarities, and the differences between one phenomenon with another phenomenon. In this study, the phenomenon was obtained through teachers' perspective of critical thinking in writing skill by looking at the strategies applied among the students in writing class. The data collection was taken from the interview with three different lectures in writing course. This research used interview guideline as an instrument to collect the data.

\section{MAIN FINDINGS}

\section{- The interpretation of Critical Thinking}

The results of the interview indicated that all of the lecturers had a good understanding of critical thinking. Participant A defines critical thinking as a logical way to develop an idea academically. Furthermore, Participant B defines critical thinking as a reasonable judgement. Moreover, Participant $\mathrm{C}$ defines critical thinking is the way people think that involves some skills, such as analysis, comprehend phenomena or information, and how to solve a problem. Overall, it could be concise as a reasonable judgement based on the sources or references. Another definition is the ability to comprehend the phenomena or information and be able to analyse it. Afterwards, the interviewees interpret the characteristics of critical thinking, such as giving a reasonable judgement, having unique ideas, delivering the idea, and doing a concise summary

\section{- The Influence of Critical Thinking in Academic Writing}

Critical thinking is important in academic writing. When a student has good critical thinking he or she would have good writing. The interview revealed that the students need to present their ideas based on references to back up their arguments. Furthermore, the way the ideas are delivered should be in chronological order and requires critical thinking to persuade or inform the readers easily. This research found that students who have high critical thinking skills are better at critical writing. 
- Improving Critical Thinking skill in Academic Writing

This research revealed that the students in Sunan Ampel Islamic State University do not apply critical thinking in academic writing. The approximately level of students' critical thinking in writing class is $30-50 \%$ as it is their first experience for having a writing class so that they do not get used to it before. The underlying factors of that phenomena are their experiences in their previous education and their first year in the university which do not require them to apply their critical thinking. Besides, The lecturers do not teach critical thinking as an independent skill, however, they apply critical thinking skill in the process of writing such as how to support the idea, how to make a draft, and how to develop their argument and show the evidence to improve the students critical thinking skills.

\section{REFERENCES}

[1] Fisher, Alec. (2011). "Critical Thinking: an introduction Second Edition”. CambridgeUniversity. Edinburgh.

[2] Moore, T. (2011). ,Critical thinking and disciplinary thinking: A continuing debate". HigherEducation Research and Development, vol. 30, 3, pp. 261-274.

[3] Watson, Goodwin, and Edward Maynard Glasser. (1952). Watson-Glaser Critical ThinkingAppraisal. Yonkers, NY; World Book Company.

[4] Vyncke Michelle. (2012). "The Concept and Practice of Critical Thinking in Academic Writing: an Investigation of International Students"Perceptions and Writing International ,S Students "Perceptions and
Experiences '.King's College. London.

[5] Development, L. (2011). Being critical when writing What is being critical? 